Ann. Parasitol. Hum. Comp., $1990,65, \mathrm{n}^{\circ} 4,162-166$.

Mémoire
Key-words: Acivicin. 6-diazo-5-oxo-L-norleucine. Glutamate. Glutamine. Plasmodium falciparum.

Mots-clés : Acivicine. 6-diazo-5-oxo-L-norleucine. Glutamate. Glutamine. Plasmodium falciparum.

\title{
METABOLISM OF GLUTAMINE IN ERYTHROCYTES INFECTED WITH THE HUMAN MALARIA PARASITE : PLASMODIUM FALCIPARUM
}

\author{
M. VILMONT, M. AZOULAY, F. FRAPPIER*
}

\begin{abstract}
SUMMARY
The metabolism of glutamine was studied in erythrocytes infected with Plasmodium falciparum, comparatively to normal cells, in presence or not of DON (6-diazo-5-oxo-L-norleucine) or acivicin, two glutamine antagonists which have been shown to inhibit the growth of $P$. falciparum in vitro.

Extracellular glutamine was partially converted into glutamate

using two routes corresponding to $\gamma$-glutamyl transpeptidase (GGT) and glutaminase activities. In cells infected with mature trophozoites, the observed enhancement of the glutamine influx and of the glutamate formation was consistent with the enhancement of GGT and glutaminase activities.

RÉsumÉ : Métabolisme de la glutamine chez l'érythrocyte infesté par Plasmodium falciparum.

Le métabolisme de la glutamine dans les globules rouges infestés par Plasmodium falciparum est étudié, comparativement aux cellules non infestées, en présence ou non de DON (6-diazo-5-oxo-Lnorleucine) ou d'acivicine, deux antagonistes de la glutamine qui ont la propriété d'inhiber la croissance de $P$. falciparum in vitro.

La glutamine extracellulaire est partiellement convertie en glu-

tamate selon deux voies correspondant à des activités de type $\gamma$-glutamyl transpeptidase (GGT) et glutaminase. Dans les globules rouges infestés par les formes trophozoïtes, on observe une augmentation de l'entrée de la glutamine et de la formation de glutamate. Le résultat est en accord avec l'augmentation des activités glutaminase et GGT.
\end{abstract}

During the development of the human malaria parasite Plasmodium falciparum in the erythrocyte, glutamine plays a central role: adequate supply of L-glutamine is effectively necessary for optimal growth of Plasmodium in vitro (Divo et al., 1985). It can be anticipated that glutamine plays a key role as a source of nitrogen in the biosynthesis of proteins or nucleic acids. Furthermore, erythrocyte is essentially impermeable to glutamate (Ellory et al., 1983) and it has been proposed that glutamine may be the precursor of glutamate which is incorporated into the glutathione pool.

In this work, we studied the metabolism of glutamine in erythrocytes infected with $P$. falciparum comparatively to that of normal cells. From our results, it appears that extracellular glutamine is partially converted into glutamate

UA CNRS 484, Faculté de Pharmacie, 4, avenue de l'Observatoire, 75270 Paris Cedex 06, France.

* Present address: UA CNRS 401, Laboratoire de Chimie, Muséum National d'Histoire Naturelle, 63, rue Buffon, 75231 Paris Cedex 05, France.

Accepté le : 19 novembre 1990. using two routes corresponding to $\gamma$-glutamyl transpeptidase (GGT) (EC 2.3.2.2.) and glutaminase (EC 3.5.1.2.). Furthermore, we studied the interaction of two glutamine antagonists: DON (6-diazo-5-oxo-L-norleucine) (Reed et al., 1980 ) and acivicin ([2S, 3S]- $\alpha$-amino-3-chloro-4,5-dihydro-5 isoxazole acetic acid) (Gardell and Tate, 1980) which have been shown to inhibit the growth of $P$. falciparum in vitro (Elford, 1983).

\section{MATERIALS AND METHODS}

Chemicals, solvents and reagents were of the highest available purity. Water was distilled twice. L- $\gamma$-glutamyl-glutamine, o-phthalaldehyde, DON, Dowex resins, RPMI were from Sigma; glutamine, glutamic acid from Janssen and L- $\gamma$-glutamyl-glutamylglutamine from Bachem. Acivicin was purchased from The Upjohn Co (Kalamazoo) and $\mathrm{L}-\left(\mathrm{U}^{14} \mathrm{C}\right)$ glutamine (SA $200 \mathrm{mCi} / \mathrm{mmol}$ ) from CEA France. $\left[{ }^{14} \mathrm{C}\right]$ oxoproline was prepared from $\left[{ }^{14} \mathrm{C}\right]$ glutamine (Dubourg and Devillers, 1956).

Just before use, glutamine was chromatographied on Dowex-1X2 anion exchange resin. The fractions eluted with water were collected and the purity of glutamine was verified by HPLC (Morineau et al., 1989).

Protein concentration was measured according to Lowry (1951), 
using bovine serum albumin as standard. TLC were performed on silica gel chromatoplates Merck 60 F254. The development solvent was butanol, pyridine, acetic acid, water: 4/6/1/4. Detection was performed by spraying with ninhydrin. Oxoprolin was visualized after treatment with $4 \mathrm{~N} \mathrm{HCl}$. HPLC measurements were monitored as previously described (Morineau et al., 1989). Scintillation counting was performed with an Inter-technique SL-30 spectrometer by the external standard method, using emulsifier scintillator 299 (Packard).

\section{Preparation OF CELLS}

Experiments described in this paper were carried out starting from leukocyte free samples prepared according to (Srivastava $e t$ al., 1976). For the assay of GGT, membrane extracts were obtained from red blood cells as described (Srivastava et al., 1976). For the determination of glutaminase activity, leukocyte free erythrocyte lysates were prepared after removing hemoglobin by DEAE cellulose treatment (Broad et al., 1978).

\section{Parasite culture}

The NF 54 strain of $P$. falciparum obtained from D. R. Druilhe was maintained by using standard in vitro techniques (Trager and Jensen, 1976). Cultures were grown in flask containing growth medium (RPMI 1640 supplemented with $25 \mathrm{mM}$ HEPES, $0.2 \%$ $(\mathrm{w} / \mathrm{v}) \mathrm{NaHCO}_{3}$ and $10 \%(\mathrm{v} / \mathrm{v})$ inactivated serum $\left.\mathrm{AB}^{+}\right)$and washed human erythrocytes at 1.0-2.5\% hematocrit. The growth medium was replaced daily and the cultures were gassed with a mixture of $90 \% \mathrm{~N}_{2}, 5 \% \mathrm{CO}_{2}$ and $5 \% \mathrm{O}_{2}$. Synchronisation was carried out either with gelatin (Jensen, 1978), or with $5 \%$ sorbitol (Lambros and Vandenberg, 1979). Immediately after sorbitol treatment, cultures consisted mainly of single and multiple ring-form infections. Three days later, cultures were always synchronized and contained essentially erythrocytes with trophozoites and schizonts of $P$. falciparum.

\section{Metabolism of GLUTAMine}

The experiments were carried out similarly starting from either normal erythrocytes or parasitized cells. The same group of infected and control cells were subjected to all the same procedure before used for parallel measurements.

\section{INFLUX OF GLUTAMINE}

The cultured cells $(50 \mu \mathrm{l})$ were collected by centrifugation at $0^{\circ} \mathrm{C}$, washed twice with $0.154 \mathrm{M} \mathrm{NaCl}$ and then suspended in $0.5 \mathrm{ml}$ of RPMI-1640 without glutamine supplemented with $\left(\mathrm{U}-{ }^{14} \mathrm{C}\right)$ glutamine $(0.85 \mathrm{mM}$, SA $16 \mathrm{mCi} / \mathrm{mmol})$. The cell suspension was gently agitated in a water bath at $37^{\circ} \mathrm{C}$. Just before and at the end of the incubation, cell concentration was measured with a Coulter Counter.

After $30 \mathrm{~min}$, the suspension was centrifuged at $0^{\circ} \mathrm{C}$ for $5 \mathrm{~min}$ at $2.000 \mathrm{~g}$ and the red cell pellet washed twice with saline. The supernatant was removed and the erythrocytes suspended in $1 \mathrm{ml}$ of saline, lysed by two freeze-thaw cycles. Then, $0.2 \mathrm{ml}$ of $15 \%$ $(\mathrm{w} / \mathrm{v})$ trichloracetic acid was added and the mixture centrifuged for $30 \mathrm{~min}$ at $13.000 \mathrm{~g}$.

Aliquot from supernatant, which contained the «total glutamine ", was assayed for $\left[{ }^{1} \mathrm{C}\right]$. The supernatant was neutralized with $1 \mathrm{~N} \mathrm{NaOH}$ and chromatographed on Dowex $1 \mathrm{X} 2$ formate form. The column ( $\mathrm{h}=4 \mathrm{~cm} ; \mathrm{d}=1 \mathrm{~cm}$ ) was eluted successively with $\mathrm{H}_{2} \mathrm{O}(40 \mathrm{ml})$ and $1 \mathrm{~N}$ formic acid $(40 \mathrm{ml})$. The radioactive aqueous fractions, which contained the "intracellular glutamine " were combined and measured by liquid scintillation counting. The radioactive acid fractions named " transformed glutamine " were collected, counted, lyophilized and analyzed: they contained glutamic acid and oxoproline. Glutamic acid was estimated by HPLC (Morineau et al., 1989). Oxoproline was characterized by TLC and estimated by HPLC, compared to authentic labeled sample, by counting the fractionated eluate. Non enzymatic formation of 5-oxoproline from glutamine was estimated from blank from which erythrocytes were omitted and substracted from the experimental values.

The data obtained from parasitized cells were extrapolated to $100 \%$ parasitemia using the following equation:

Rate $100 \%$ parasitemia $=$ [rate of infected culture - rate of uninfected $(1-\mathrm{P})] / \mathrm{P}$

where $\mathrm{P}$ is the fractional parasitemia (ring form + trophozoïte + schizont).

$\gamma$-GLUTAMYL TRANSFERASE ASSAY

Membrane extract (containing 0.3 to $1 \mathrm{mg}$ protein) was mixed, in a final volume of $1 \mathrm{ml}$, with $50 \mathrm{mM}$ Tris $\mathrm{HCl}, \mathrm{pH} 8.5$ buffer containing $5 \mathrm{mM} \mathrm{MgCl}$ and $20 \mathrm{mM}\left[{ }^{14} \mathrm{C}\right]$ glutamine (SA $1 \mathrm{mCi}$ / mmol). After $30 \mathrm{~min}$ incubation at $37^{\circ} \mathrm{C}$ the reaction was terminated by adding $0.25 \mathrm{ml}$ of $15 \% \mathrm{TCA}$. The mixture was centrifuged at $13.000 \mathrm{~g}$ for $20 \mathrm{~min}$ at $0^{\circ} \mathrm{C}$. The supernatant was neutralized by $1 \mathrm{~N} \mathrm{NaOH}$ and chromatographied on $\mathrm{Ag} 1 \mathrm{X} 2$, formate form. The radioactive fractions eluted with $1 \mathrm{~N}$ formic acid were lyophilized. Glutamate, $\gamma$-glu-gln and $\gamma$-glu-glu-gln were determined by HPLC (Morineau et al., 1989).

The experiments in presence of acivicin or DON were conducted similarly after preincubation with $20 \mathrm{mM}$ inhibitor at $37^{\circ} \mathrm{C}$ for $30 \mathrm{~min}$.

\section{Glutaminase ASSAY}

Purified hemolysate containing 0.5 to $1.0 \mathrm{mg}$ protein was mixed, in final volume $1 \mathrm{ml}$, with $50 \mathrm{mM}$ Tris $\mathrm{HCl}, \mathrm{pH} 8.6$, containing $60 \mathrm{mM}$ potassium phosphate, $0.2 \mathrm{mM}$ EDTA and $10 \mathrm{mM} \mathrm{L}$ $\left[\mathrm{U}^{-14} \mathrm{C}\right]$ glutamine (SA $1 \mathrm{mCi} / \mathrm{mmol}$ ). After $30 \mathrm{~min}$ incubation at $37^{\circ} \mathrm{C}$, the reaction was treated as above for glutamate determination. Studies in presence of DON or acivicin were monitored after $30 \mathrm{~min}$ preincubation at $37^{\circ} \mathrm{C}$ with $20 \mathrm{mM}$ inhibitor.

\section{RESULTS}

The metabolism of glutamine was studied in erythrocytes infected with Plasmodium falciparum comparatively to normal cells.

Erythrocytes were incubated in RPMI-1640 medium containing $\left[{ }^{14} \mathrm{C}\right]$ glutamine $(0.85 \mathrm{mM})$. After $30 \mathrm{~min}$, the cells were lysed and treated by trichloracetic acid (TCA). The TCA supernatant which corresponded to the «total intracellular glutamine" was chromatographied on Dowex-1-anion exchange resin. The radioactive fractions eluted with water contained glutamine. The acidic eluate named « transformed glutamine » contained $\left[{ }^{14} \mathrm{C}\right]$ glutamate and oxoproline (Table I) which were estimated by TLC and by HPLC. During the treatment of the reaction, non enzymatic formation of radioactive oxoproline was 
TABlE I. - Metabolism of $\left[{ }^{14} \mathrm{C}\right]$ glutamine in uninfected and P. falciparum infected erythrocytes.

\begin{tabular}{lrllll}
\hline & \multicolumn{4}{c}{ Red cells } \\
\cline { 2 - 5 } & \multicolumn{4}{c}{ uninfected } & \multicolumn{3}{c}{ infected } \\
\hline Total glutamine & $0.73^{\mathrm{a}} \pm 0.14$ & $5.63^{\mathrm{a}, \mathrm{b}} \pm 0.40$ & $(7.7)^{\mathrm{c}}$ \\
Glutamine & 0.28 & \pm 0.12 & 0.33 & \pm 0.24 & $(1.2)$ \\
Transformed glutamine & $0.10 \pm 0.04$ & 1.94 & \pm 0.63 & $(18.8)$ \\
Glutamate & 0.018 & \pm 0.08 & 0.33 & \pm 0.17 & $(18.6)$ \\
Oxoproline & 0.085 & \pm 0.03 & 1.53 & \pm 0.53 & $(18.0)$ \\
& & & & & \\
\hline
\end{tabular}

After 30 min preincubation in RPMI supplemented with $\left[{ }^{14} \mathrm{C}\right]$ glutamine, erythrocytes were treated as described in Materials and Methods. The same group of infected and control cells were used for parallel measurements: a) the results are expressed as pmol per $10^{8}$ cells; b) values normalized to $100 \%$ parasitemia; c) figures in brackets indicate the ratio infected cells/uninfected cells. The distributions of parasite form (ring form, mature trophozoïe, schizont) were (\%) : 2.9-4.5-2.6; 2.3-2.7-2.4; 3.5-4.6-2.0. Values represent the mean of three duplicate experiments \pm SD.

observed. The quantity formed was estimated from blank, without enzymatic extract and substracted from the experimental values.

Infected erythrocytes harbouring young parasite stages were isolated by the gelatin gradient method (Jensen, 1978) and incubated in RPMI medium containing $\left[{ }^{14} \mathrm{C}\right]$ glutamine. Starting from three samples cultured at parasitemia of between 7 and $8 \%$, no significative change in the intracellular glutamine accumulation and glutamate formation was observed.

Then, experiments were monitored starting from cells parasitized with mature trophozoites and schizonts. In this case, an enhancement of the total intracellular glutamine was found. When the data were extrapolated to $100 \%$ parasitemia, the glutamine influx rose to 7.7 fold higher than that in uninfected cells. Similar, increases were measured for transformed glutamine, glutamate and oxoproline formations (18 fold) (Table I).

From these results, it is apparent that glutamine can be deaminated intracellularly to glutamate. The formation of glutamate suggests a reaction catalysed either by glutaminase (Kwamme et al., 1985) or GGT (Cook and Timothy, 1986).

\section{GGT ACTIVIY}

Rat kidney GGT can utilize glutamine as substrate and catalyzes two types of reaction: transpeptidation and hydrolysis in which the $\gamma$-glutamyl moiety is transfered respectively to an amino-acid (or dipeptide) and to water (Dass,
1983). So, the GGT activity was estimated from erythrocyte membrane using $\left[{ }^{14} \mathrm{C}\right]$ glutamine $(20 \mathrm{mM}, 0.1 \mathrm{mCi} / \mathrm{mmol})$ as substrate. Glutamate, $\gamma$-glu-gln and $\gamma$-glu-glu-gln were determined by HPLC (Morineau et al., 1989). Enzymatic formation of oxoproline was not observed, after comparison with a blank obtained without enzymatic extract.

GGT activity was measured in infected cells compared to uninfected. In normal erythrocyte, $0.48 \pm 0,18 \mathrm{nmol}$ of glutamine were transformed into glutamate per min and per mg protein. This value corresponds to the hydrolase activity of GGT (Cook and Timothy, 1986). The amounts of transfer products: $\gamma$-glu-gln and $\gamma$-glu-glu-gln which were found to be respectively $0.28 \pm 0.17$ and $0.20 \pm$ $0,02 \mathrm{nmol} \cdot \mathrm{min}^{-1} \mathrm{mg}^{-1}$ protein can be attributed to the transpeptidase activity of GGT (Dass, 1983). In infected cells, hydrolase activity rose to 24 to 28 higher values compared to control erythrocytes, when the data were extrapolated to $100 \%$ parasitemia. In contrast, little variations were observed concerning the peptides formation (Table II).

Furthermore, erythrocyte membrane extracts were preincubated $30 \mathrm{~min}$ with $20 \mathrm{mM}$ DON or acivicin, and then glutamine added. For each one of the glutamine analogs, the formation of glutamate from glutamine decreased dramatically. In the case of the infected cells, the hydrolase activity was inhibited (70 \% and $55 \%$ respectively compared to controls without inhibitor), when a total inhibition was observed in the case of normal erythrocytes (Table III).

\section{Glutaminase aCtivity}

Glutaminase catalyzes the reaction L-glutamine + $\mathrm{H}_{2} \mathrm{O} \rightarrow$ L-glutamate + ammonia (Kwamme et al., 1985). Glutaminase activity was assayed starting from leukocytesfree erythrocyte lysate after removing hemoglobin by DEAE cellulose treatment. Purified hemolysates were incubated with $10 \mathrm{mM}$ glutamine and glutamate formed was estimated, as above, by HPLC after derivatization with ophthaldehyde (Morineau et al., 1989). In normal erythrocyte, glutaminase activity was found to be $1.24 \pm 0.14 \mathrm{nmol}$ glutamate formed per min per mg protein. Enzymatic activity was linear from 5 to $20 \mathrm{~min}$ and proportional to the amount of proteins contained in the sample up to $1.2 \mathrm{mg}$. Glutaminase activity was also estimated from purified hemolysates obtained from parasitized erythrocytes. Compared to controls, the glutamate formation increase (10 to 15 fold when the values were extrapolated to $100 \%$ parasitemia).

In the presence of $20 \mathrm{mM}$ DON and after $30 \mathrm{~min}$ preincubation, glutamate formation measured from infected cells was inhibited. Acivicin was a less potent inhibitor (Table III), as previously described in the case of the renal enzyme (Shapiro et al., 1979; Shapiro and Curthoys, 1981). 
TABLE II. - Synthesis of glutamate, $\gamma$-glu-glu and $\gamma$-glu-glu-gln from glutamine in normal and $P$. falciparum infected erythrocytes membrane extract.

\begin{tabular}{|c|c|c|c|c|}
\hline Erythrocytes & $\begin{array}{l}\text { Pretreatment of }{ }^{\text {a }} \\
\text { membrane extract }\end{array}$ & glu & $\gamma-g l u-g \ln$ & $\gamma-g l u-g l u-g l n$ \\
\hline \multirow[t]{3}{*}{ Uninfected } & none $^{b}$ & $0.48 \pm 0.18$ & $0.28 \pm 0.17$ & $0.20 \pm 0.02$ \\
\hline & DON & \# 0 (100) & $0.02(93)$ & $0.04(80)$ \\
\hline & acivicin & \# 0 (100) & $0.18(35)$ & $0.09(55)$ \\
\hline \multirow[t]{2}{*}{ Infected $^{c}$} & none & 1.58 & 0.37 & 0.08 \\
\hline & DON & $47(70)$ & $0.17(55)$ & $0.04(50)$ \\
\hline \multirow[t]{2}{*}{ Infected $^{d}$} & none & 1.40 & 0.27 & 0.18 \\
\hline & acivicin & $0.64(55)$ & 0.17 (37) & $-{ }^{e}$ \\
\hline
\end{tabular}

The experiments were monitored as described in Methods. Results are expressed as nmol per min per mg protein. Figures in brackets indicate the percentage of inhibition. a) Preincubation for $30 \mathrm{~min}$ at $37^{\circ} \mathrm{C}$ with $20 \mathrm{mM}$ inhibitor. b) Values represent the mean of three duplicate experiments $\pm \mathrm{SD}$. The distribution of parasite forms (ring form, mature trophozoite, schizont) was (\%): c) $2.7,7.0$, 4.0. d) 1.9, 1.6, 3.5. e) Not determined.

TABLE III. - Inhibition of GGT and glutaminase activities in uninfected and infected red cells by DON and acivicin.

\begin{tabular}{lcccc}
\hline \multicolumn{1}{c}{ Red cells } & Uninfected & Infected & \\
\hline Pretreated with $_{\text {GGT activity }}^{\mathrm{a}}$ & DON & Acivicin & DON & Acivicin \\
Glutaminase activity $^{\mathrm{b}}$ & 100 & 100 & $70(60)^{\mathrm{c}}$ & $55(33)$ \\
\hline
\end{tabular}

The results are expressed as percentage of inhibition compared to controls without inhibitor. The experiments were monitored as described in Methods, starting from (a) erythrocyte membrane extract, (b) purified hemolysate, after preincubation with $20 \mathrm{mM}$ inhibitor for $30 \mathrm{~min}$ at $37^{\circ} \mathrm{C}$. The distribution of parasite forms (ring form, mature tropophozoite, schizont) were \%: 1.9-1.6-3.5; 0.35-1.9-2.75. c) Figures in brackets indicate the percentage of inhibition normalized to $100 \%$ parasitemia. Values represent the mean of two duplicate experiments.

\section{DISCUSSION}

From this work, it is apparent that in normal erythrocyte and cell infected with $P$. falciparum, glutamine can be deaminated intracellularly to glutamate. The presence of GGT in normal erythrocyte is in dispute (Beutler and Dale, 1989; Daniel et al., 1987). However, our results suggest that the glutamine $\rightarrow$ glutamate transformation is catalysed by two enzymes: glutaminase and $\gamma$-glutamyl-transpeptidase (GGT) as depicted in figure 1 : glutamine penetrate the red cells (in normal cells, mainly through a saturable sodium dependent process (Ellory et al., 1983) and the intracellular glutamine may be converted into glutamate through glutaminase. GGT, which is membrane bound utilizes glutamine as substrate and catalyses two types of reaction: transpeptidation in which the $\gamma$-glutamyl moiety is transferred to an amino-acid and hydrolysis in which the glutamyl moiety is transferred to water. Oxoproline formation is due to the presence of $\gamma$-glutamyl cyclotransferase (Broca et al., 1978; York et al., 1984) which catalyses the reaction L- $\gamma$ glutamyl amino-acid $\rightarrow$ 5-oxoproline + amino-acid.

In cells parasitized with mature trophozoites, an increase in the flux of glutamine was previously described (Elford

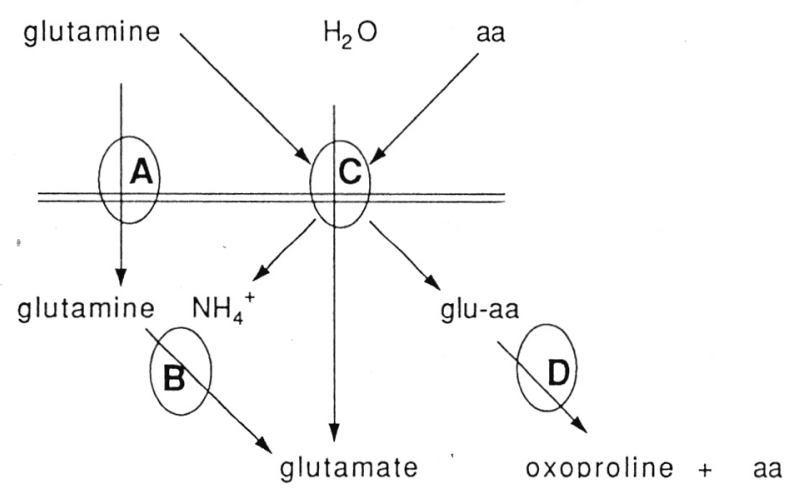

Fig. 1. - Proposed pathways of glutamine influx in human erythrocyte. Enzymes: $\mathrm{Na}^{+}$dependent transporter (A), glutaminase (B), $\quad \gamma$-glutamyltranspeptidase (C), $\quad \gamma$-glutamylcyclotransferase (D); aa = amino-acid.

et al., 1985). In our hands, the intracellular glutamine pool increases 7.7 fold, when parasitemia was normalized to $100 \%$.

Furthermore, similar enhancements of transformed glutamine and glutamate were observed. These results are in agreement with the increases of GGT and glutaminase acti- 
vities measured from membrane extracts and lysed cells respectively.

However, from this work, it is not possible to conclude that glutaminase and GGT are present in P. falciparum : the enhancement of the enzymatic activities observed in the host cells may be due to the invasion process of the parasite.

As mentioned above, DON and acivicin have been shown, using a growth assay based on ${ }^{3} \mathrm{H}$ hypoxanthine incorporation (Desjardin et al., 1979) to inhibit the growth of $P$. falciparum. In our hands, the $\mathrm{IC}_{50}$ values were found to be both $0.35 \mu \mathrm{M}$ (unpublished results).

However, one can not state that inhibition of parasite growth by the two glutamine analogs is due to inhibition of GGT and glutaminase. Nevertheless, the study of the interaction of the two drugs with the metabolism of glutamine in parasitized erythrocytes presented an attractive biochemical aspect in the context of the research of new antimalarial drugs.

Acknowledgments. - We are grateful to the Laboratoire de Parasitologie from Centre de Recherche de Vitry, Rhône-Poulenc. Santé for the in vitro antimalarial test results. We thank Dr M. A. Mouriès for helpful discussions.

\section{REFERENCES}

Beutler E., Dale G. L. : Erythrocyte glutathione: function and metabolism. In: Glutathione. Chemical Biochemical and Medical Aspects, Part B (Ed. Dolphin D., Avramovic O. and Poulson R.), 291-315. John Wiley, New York, 1989.

Broad P. G., Moore K. A., Smith J. E. : Purification and properties of $\gamma$-glutamyl-cyclotransferase from human erythrocytes. Biochem. J., 1978, 173, 427-431.

Cook N. D., Timothy J. P. : The simultaneous hydrolysis of glutathione and glutamine by rat kidney $\gamma$-glutamyl-transferase. Biochim. Biophys. Acta, 1986, 884, 207-210.

Daniel D. S., Ramakrishna B. S., Balasubramanian K. A. : Human erythrocyte $\gamma$-glutamyl-transferase in liver deseases. Clin. Chim. Acta, 1987, 162, 319-327.

Dass P. D. : Glutamine as a $\gamma$-glutamyl donor for $\gamma$-glutamyl transpeptidase: $\gamma$-glutamyl peptide formation. Life Sci., 1983, 33, 1757-1762.

Desjardins R. E., Canfield C. J., Haynes J. D., Chulay J. D. : Quantitative assessment of antimalarial activity in vitro by a semi-automated microdilution technique. Antimicrob. Agents Chemother., 1979, 16, 710-718.
Divo A. A., Geary T. G., Davis N. L., Jensen J. B. : Nutritional requirements of Plasmodium falciparum in culture. Exogenously supplied dialyzables components necessary for continuous growth. J. Protozool., 1985, 32, 59-64.

Dubourg J., Devillers P. : Transformation de l'acide glutamique et de la glutamine en acide pyrolidone carboxylique et ce dernier en acide glutamique. Bull. Soc. Chim. France, 1956, 1351-1355.

Elford B. C. : L-Glutamine influx in malaria-infected erythrocytes: a target for antimalarials? Parasitol. Today, 1986, 2, 309-312.

Elford B. C., Haynes J. D., Chulay J. D., Wilson R. J. M. : Selective stage-specific changes in the permeability to small hydrophilic solutes of human erythrocytes infected with Plasmodium falciparum. Mol. Biochem. Parasitol., 1985, 16, 43-60.

Ellory J. C., Preston R. L., Osatimahin B., Yound J. D. : Transport of amino-acids for glutathione biosynthesis in human and dog red cells. Biomed. Biochim. Acta, 1983, 42, S48-S52.

Gardell S. J., Tate S. S. : Affinity labeling of $\gamma$-glutamyl-transpeptidase by glutamine antogonists. FEBS Lett., 1980, 122, 171-178.

Jensen J. B. : Concentration form continuous culture of erythrocytes infected with trophozoites and schizonts of Plasmodium falciparum. Am. J. Trop. Med. Hyg., 1978, 27, 1274-1275.

Kwamme E., Ingeborg A. A. T., Svenneby G. : Glutaminase from mammalian tissues; Methods Enzymol., 1985, 113, 241-256.

Lambros C., Vandenberg J. P. : Synchronisation of Plasmodium falciparum erythrocytic stages in cultures. J. Parasitol., 1979, 54, 416-424.

Lowry O. H., Rosebrough N. J., Lewis Farr A., Randall R. J. : Protein measurements with the Folin phenol reagent. J. Biol. Chem., 1951, 153, 265-275.

Morineau G., Azoulay M., Frappier F. : Reaction of o-phthaldehyde with amino-acids and glutathione; Application to high performance liquid chromatography determination. J.Chromatogr., 1989, 467, 209-216.

Reed D. J., Ellis W. W., Meck R. A. : The inhibition of $\gamma$-glutamyl transpeptidase and glutathione metabolism of isolated rat kidney cells by L-(2S, 5S)- $\alpha$-amino-3-chloro-4,5-dihydro-5-isoxazoleacetic acid (AT-125, NSC-163501). Biochem. Biophys. Res. Comm., 1980, 94, 1273-1277.

Shapiro R. A., Clark V. M., Curthoys N. P. : Inactivation of rat renal phosphate-dependent glutaminase with 6-diazo-5-oxonorleucine. J. Biol. Chem., 1979, 254, 2835-2838.

Shapiro R. A., Curthoys N. P. : Differential effect of AT 125 on rat renal glutaminase activities. Febs Lett., 1981, 133, 131-134.

Srivastava S. K., Yogesh C. A., Steven P. M., Yoshida A., Beutler E. : Studies on $\gamma$-glutamyl transpeptidase in human and rabbit erythrocytes. Blood, 1976, 47, 645-650.

Trager W., Jensen J. B. : Human malaria parasites in continuous culture. Science, 1976, 193, 673-675.

York M. J., Kuchel P. W., Chapman B. E. : A proton nuclear magnetic resonance study of $\gamma$-glutamyl amino-acid cyclotransferase in human erythrocyte. J. Biol. Chem., 1984, 259, 15085-15088. 